\title{
Pharmaciana
}

Vol. 8, No.1, May 2018, Page. 43-52

ISSN: 2088 4559; e-ISSN: 24770256

DOI: $10.12928 /$ pharmaciana.v8i1.8988

\section{The gastroprotective effects of canna edulis ker. tuber starch on peptic ulcer and the histopathological profile of rat stomach}

\author{
Robby Najini, Moch. Saiful Bachri*, Sapto Yuliani \\ Faculty of Pharmacy University of Ahmad Dahlan \\ Jl. Prof. Dr. Soepomo, S.H., Janturan, Yogyakarta
}

\begin{abstract}
Canna edulis Ker. tuber is empirically useful for treating gastritis (peptic ulcers). It contains carbohydrates and flavonoids that can reduce the inflammation of gastric cells and counteract free radicals, which also contribute to the pathogenesis of peptic ulcers. This research aimed to identify the gastroprotective effects of Canna edulis Ker. on white female rats of Wistar strain that received 1 $\mathrm{ml} / 200 \mathrm{~g}$ of $96 \%$ ethanol and to measure the total flavonoid content in this tuberous plant. This research employed Post-test Only Control Group design using 30 rats with a weight of 150-200 g, age of 6-8 weeks, and healthy condition. Based on the treatment they received, these rats were classified into six groups. Group I (normal) was only fed and given drinking water. Group II (control) was given $0.5 \%$ CMC-Na. Groups III, IV, and V received a suspension of Canna edulis Ker. tuber starch and water (SCTS) at different doses, namely, 250, 500, and 1,000 mg/kg BW, respectively. Group VI was treated with sucralfate at $360 \mathrm{mg} / \mathrm{kg} \mathrm{BW}$. Each group received oral treatment for 14 days. An hour after the treatment on Day 14, Groups II-VI were given $1 \mathrm{~mL} / 200 \mathrm{~g} \mathrm{BW}$ of $96 \%$ ethanol orally. Twenty-four hours later the rats were sacrificed and dissected, and their stomachs were removed for further analysis, including on the extent of peptic ulcers and the histopathological profile of the rat stomach. The results showed that SCTS reduced the peptic ulcers index and increased the protection ratio. As compared to the control group, the protection ratio of different doses of SCTS, i.e., 250, 500, and $1,000 \mathrm{mg} / \mathrm{kg} \mathrm{BW}$, were $12.5,50$, and $75 \%$, respectively. The histopathological profiles showed a significant improvement of gastric tissue in rats treated with $1,000 \mathrm{mg} / \mathrm{kg}$ BW of SCTS. Also, the TLC-densitometry test revealed that the total flavonoid content in Canna edulis Ker. was $112.49 \pm$ $7.97 \mathrm{ppm}$. As a conclusion, Canna edulis Ker. positively contains flavonoids and, therefore, has beneficial gastroprotective effects as it can reduce the ulcer index, increase the protection ration, and improve the histopathological sign of alcohol-induced gastritis.
\end{abstract}

Keywords: Canna edulis Ker. tuber starch, peptic ulcer, gastroprotective, total flavonoids

\section{Corresponding author:}

Moch. Saiful Bachri

Faculty of Pharmacy University of Ahmad Dahlan

Jl. Prof. Dr. Soepomo, S.H., Janturan, Yogyakarta

Email: msaifulbachri@yahoo.co.id 


\section{INTRODUCTION}

Gastritis or peptic ulcer is a health problem that often appears in the form of wound or abrasion on gastric mucosa (Turner, 2010). The triggers are irregular eating habits, the ingestion of drugs that have irritating side effects on the stomach, or the consumption of certain irritative foods or beverages, such as alcohol that can damage gastric mucosal barrier (Guyton, 2008).

If consumed, alcohol brings toxic effects on the body either directly or indirectly because it dissolves fat and is therefore distributed by the blood throughout the body quickly. Also, it contains free radicals that can damage the mucous membrane, causing bleeding in the stomach. Long-term alcohol poisoning potentially leads to liver and kidney damage, central nervous system disorders, and even death (Wibisono, 2012).

Gastritis is treateable with herbs that contain flavonoid compounds, such as turmeric, Javanese ginger (Curcuma zanthorrhiza), honey, and Gotu Kola (Centella asiatica) (Hariana, 2013). Empirically, there is one plant used commonly by the public to treat gastritis, namely Canna edulis Ker. (Lestari, 2008). It contains polysaccharides (Kusbandari and Lukitaningsih, 2013), polyphenols, flavonoids, and proanthocyanidins (Mishra et al., 2011). All of these compounds are claimed to possess good effects that can protect the stomach from severe diseases associated with peptic ulcers.

Some of the active ingredients known to treat peptic ulcers are alkaloids (Falcao et al., 2008) and flavonoids (Abdel-Raheem, 2010). Flavonoids are effective in inhibiting the activity of cyclooxygenase enzyme and, consequently, the formation of prostaglandins from arachidonic acid. The later reduces the inflammation of gastric cells (Miller, 2003) and counteracts free radicals that play a role in the pathogenesis of peptic ulcer (de Lira Mota et al., 2009).

Lestari (2008) proves that when administered with concentrations of 50 and $100 \%$, the juice of Canna edulis Ker. tuber exhibits antiulcer activity on white male Wistar rats that were induced with $135 \mathrm{mg} / \mathrm{g} \mathrm{BW}$ of aspirin. Kusbandari and Lukitaningsih (2013) affirm that the administration of powder simplicia and Canna edulis Ker. tuber starch, as well as glucomannan, can reduce gastrointestinal inflammation and hemorrhage in the stomach of the tested rats treated with acetylsalicylic acid. Both powder simplicia and Canna edulis Ker. tuber starch can give a protection ratio of up to $81.13 \%$, while glucomannan can provide $58.49 \%$ protection.

Based on the description above, this research aimed to identify the gastroprotective effects of Canna edulis Ker. on stomach after alcohol consumption and measure the total flavonoid content in this tuberous plant.

\section{MATERIALS AND METHODS}

This experimental study used the Post-test Only Control Group design, which involves administering a treatment to several groups (control and treatment groups) and measuring and comparing the effects shown by these experimental groups (Yanwirasti, 2008).

\section{Tools and Materials}

This research produced Canna edulis Ker. tuber powder using a blender (Maspion). The Canna edulis Ker. tuber starch was prepared using glassware, such as measuring glass (Pyrex), glass beaker (Pyrex), stirring bar, and analytical scale (HWH). As for the animal testing, it used mouse cages, weights (Ohaus), oral syringes, and Petri dishes (Pyrex). The area of peptic ulcer bleeding was measured with a software application, namely ImageJ.

This research used white female Wistar rats with a weight of 150-200 g, age of 6-8 weeks, and healthy condition obtained from the Integrated Research and Testing Laboratory (LPPT) Universitas Gadjah Mada, Yogyakarta. These rats were fed with AD II. This research used the tuber part of Canna edulis Ker., which was purchased from farmers through the traders in Beringharjo Market, Yogyakarta. The material used to sacrifice the test animal was $\mathrm{CO}_{2}$ gas. The solvent for the test was 
0.5\% CMC-Na solution acquired from the Pharmacology Laboratory, Faculty of Pharmacy, Ahmad Dahlan University.

\section{Research Procedure \\ Plant Determination}

The plant determination aimed to ensure that the plant material used in the experiment is indeed Canna edulis Ker.

\section{The preparation of Canna edulis Ker. Tuber Starch}

The Canna edulis Ker. tuber was processed into powder through several stages. First, the tuber was peeled off, washed under running water, and then cut into pieces with a thickness of 1-5 mm. These pieces were dried under direct sunlight. Once dried, they were ground into powder in a blender.

To separate the starch, the powder was mixed with water and then pressed firmly until the texture was porridge-like. Afterward, it was placed on a filter cloth and squeezed firmly. The residues were deposited in the cloth, while the mixture of water and Canna edulis Ker. tuber starch passed through it. The residues were repeatedly mixed with water and strained until the juice was clear or completely extracted. This juice was a suspension that was later left for deposition in the tub for one night or approximately 12 hours. When the starch was deposited (the water in the tub was clear), the tub was tilted slowly allowing the water to spill. The starch was air-dried to reduce the remaining water and then placed in a container and dried directly under the sun. During the drying process, it was flipped several times and pressed to reduce the drying time and prevent clumping. If the starch was dry but still clumped, then it required more pounding to produce finer starch.

\section{The measurement of total flavonoid content}

The identification of the flavonoid content used a series of standard quercetin solution and a calibration curve. Around $10 \mathrm{mg}$ of quercetin was dissolved in ethanol p.a. in a 10-mL measuring flask and shaken until homogenous. Six series of standard solutions were prepared with concentrations of $50,75,100,125,150$, and $175 \mathrm{ppm}$. Afterward, the sample solution was prepared by dissolving $1 \mathrm{~g}$ of Canna edulis Ker. tuber starch with ethanol p.a. in a 10-mL measuring flask. It was shaken until homogeneous. The standard quercetin solution and $2 \mu \mathrm{l}$ of the sample solution were each spotted ten times on silica gel 60 F254 plates, expanded with a mobile phase of 9:3 chloroform/methanol, and then measured with TLC-Densitometry at a wavelength of $254 \mathrm{~nm}$ (Wardhani and Sulistyani, 2012).

\section{Test animal classification and treatment}

This research used 39 rats and divided them into six groups, each consisting of 5 rats. Group I (normal) was given food and water only. Group II (control) was given 0.5\% CMC-Na. Groups III, IV, and V received a suspension of Canna edulis Ker. tuber starch and water (SCTS) at different doses, namely, 250, 500, and 1,000 mg/kg BW, respectively. Group VI was treated with sucralfate at 360 $\mathrm{mg} / \mathrm{kg} \mathrm{BW}$. Each group received oral treatment for 14 days. An hour after the treatment on Day 14, Groups II-VI were given $1 \mathrm{~mL} / 200 \mathrm{~g} \mathrm{BW}$ of $96 \%$ ethanol orally. Twenty-four hours later the test animals were sacrificed and dissected, and their stomachs were removed for further analysis, including on the extent of peptic ulcers and the histopathological profile of the rat stomach (Pertiwi and Bachri, 2016).

\section{Microscopic observation on peptic ulcers}

After surgery, the stomach was isolated to determine the number and size of lesions/ulcers formed on the gastric mucosa. The stomach was opened by dissecting the major curvature, cleansed with $0.9 \% \mathrm{NaCl}$ solution, and then stretched on a flat surface; the ulcers formed on the lining of the stomach were observed afterward (Gusdinar et al., 2009). ImageJ analysis was used to see the percentage of the inflamed areas (ulcers). The analysis results were then affirmed by observing the 
ulcers and assigning numerical scores on them. Score 0 represents no pathological change (normal). Scores $1,2,3,4$, and 5 were assigned to bleeding areas with different extents, namely $0.0-5.0 \%, 5.1$ $10.0 \%, 10.1-15.0 \%, 15.1-20.0 \%$, and $>20.0 \%$, respectively.

The ability to protect, or protection ratio, was calculated using the following equation:

$$
\% \text { Protection Ratio }=100 \%-\left[\frac{\text { IU of test group }}{\text { IU of control group }} \times 100 \%\right]
$$

(Saptarini et al., 2011)

\section{Histopathological examination}

The stomach was washed with $0.9 \% \mathrm{NaCl}$, placed in a pot, weighed, and then submerged in $10 \%$ formalin solution for histopathological preparations (Pospos, 2002).

\section{Data Analysis}

The extent and percentage of the bleeding areas identified in ImageJ (gastric ulcer index), as well as gastric damages on the histopathological profiles, were analyzed statistically using SPSS 20 at 95\% confidence level.

The histopathological profile of the rat stomach that suffered from alcohol-induced gastritis was observed under a light microscope. The slice preparations of the stomach were analyzed by identifying any specific changes occurring in the stomach (Maslachah et al., 2008).

\section{RESULTS AND DISCUSSION}

\section{The Determination of Canna edulis Ker.}

The determination process showed that the plants used in this research were indeed Canna edulis Ker.

\section{The Preparation of Canna edulis Ker. Tuber Starch}

This research used the starch of Canna edulis Ker. tuber purchased from traders in Beringharjo traditional market, Yogyakarta. The reaction yield of the starch was $21.25 \%$.

\section{The Total Flavonoid Content of Canna edulis Ker. Tuber Starch}

Total flavonoid content was analyzed in this research because flavonoids were assumed to be one of the beneficial compounds in Canna edulis Ker. tuber starch. It was detected using TLCDensitometry because this method is sensitive, selective, easy, fast, and economical (Yuangsoi et al., 2008).

The calibration curve of the standard quercetin solution is presented in Figure 1. Meanwhile, the flavonoid detection test results are summarized in Table I. The measured total flavonoid content of Canna edulis Ker. tuber starch was $112.49 \pm 7.97 \mathrm{ppm}$. In other words, the starch positively contains flavonoids. This finding is in line with Mishra et al., (2011). Flavonoids work by inhibiting the cyclooxygenase enzyme and, at the same time, the formation of prostaglandins from arachidonic acid. This inhibition reduces the inflammation of stomach cells (Miller, 2003) and counteracts free radicals that play a role in the pathogenesis of peptic ulcer (de Lira Mota et al., 2009). 


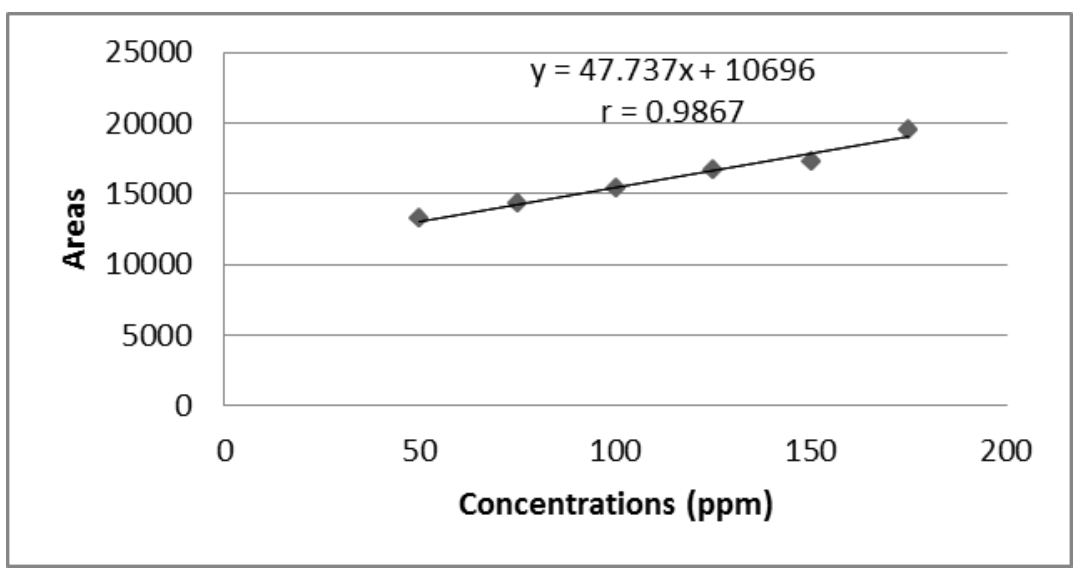

Figure 1. The calibration curve of quercetin solution

Tabel I. The total flavonoid content of Canna edulis Ker. tuber starch, as measured with densitometric thin chromatography layer (TLC)

\begin{tabular}{cccc}
\hline Starch Samples & Areas & Concentrations $(\mathbf{p p m})$ & $\overline{\mathbf{x}} \pm \mathbf{S D}$ \\
\hline $1^{\text {st }}$ replication & 15902.73 & 109.09 & \\
$2^{\text {nd }}$ replication & 15792.63 & 106.78 & $112.49 \pm 7.97$ \\
$3^{\text {rd }}$ replication & 16499.91 & 121.60 & \\
\hline
\end{tabular}

\section{The characteristics of peptic ulcers}

The macroscopic pictures of the rat stomach are presented in Figure 2. These images were further analyzed in ImageJ to measure the percentage of the surface areas of peptic ulcers (\%). The analysis results were supported by the parameter ulcer index, which in this case was used to determine the protection ratio of Canna edulis Ker. tuber starch against alcohol poisoning.

The results of the macroscopic observation in ImageJ are summarized in Table II. Afar the distribution of peptic ulcers was identified, the percentage of the bleeding areas were analyzed statistically in SPSS 20 with a confidence level of 95\%. This analysis found that the extent of bleeding areas in the normal group was significantly different from the percentage of stomach areas with peptic ulcers in the other groups (i.e., the control group, the sucralfate-treated group, and the ones receiving SCTS at 250, 500, and $1,000 \mathrm{mg} / \mathrm{kg} \mathrm{BW}$ ). This finding proved that alcohol (96\% ethanol) consumption at a dose of $1 \mathrm{ml} / 200 \mathrm{~g} \mathrm{BW}$ (Pertiwi and Bachri, 2016) induced ulcers on rat stomach.

Table II presents that the only pair of groups that have no significant difference is the control group and the one receiving SCTS at a dose of $250 \mathrm{mg} / \mathrm{kg} \mathrm{BW}$. This result indicates that at this concentration, Canna edulis Ker. tuber starch does not exhibit any gastroprotective effects on the test animal (rat).

The statistical analysis results showed that Canna edulis Ker. tuber starch affected the extent of stomach area (\%) that suffered from ulcers, as well as the ulcer index and the protection ratio. The most favorable percentage (i.e., only $0.77 \pm 0.18 \%$ ) was found in the group treated with SCTS at a dose of $1,000 \mathrm{mg} / \mathrm{kg} \mathrm{BW}$. Consequently, the administration of Canna edulis Ker. tuber starch in this portion was considered to have the best effect because the stomach surface was only slightly affected by alcohol-induced peptic ulcers, as compared to the other groups. This finding is also supported by the decreased ulcer index and the increased protection ratio. The protection ratio has a positive linear relationship with the dose of Canna edulis Ker. tuber starch, as evidenced by the highest protection 
ratio (75\%) found in the group receiving the highest dose of Canna edulis Ker. tuber starch in this research, i.e., $1,000 \mathrm{mg} / \mathrm{kg} \mathrm{BW}$. This result also suggests that Canna edulis Ker. tuber starch can improve the stomach

condition by decreasing the ulcer index and increasing the protection ratio from alcohol-induced peptic ulcers in rats.

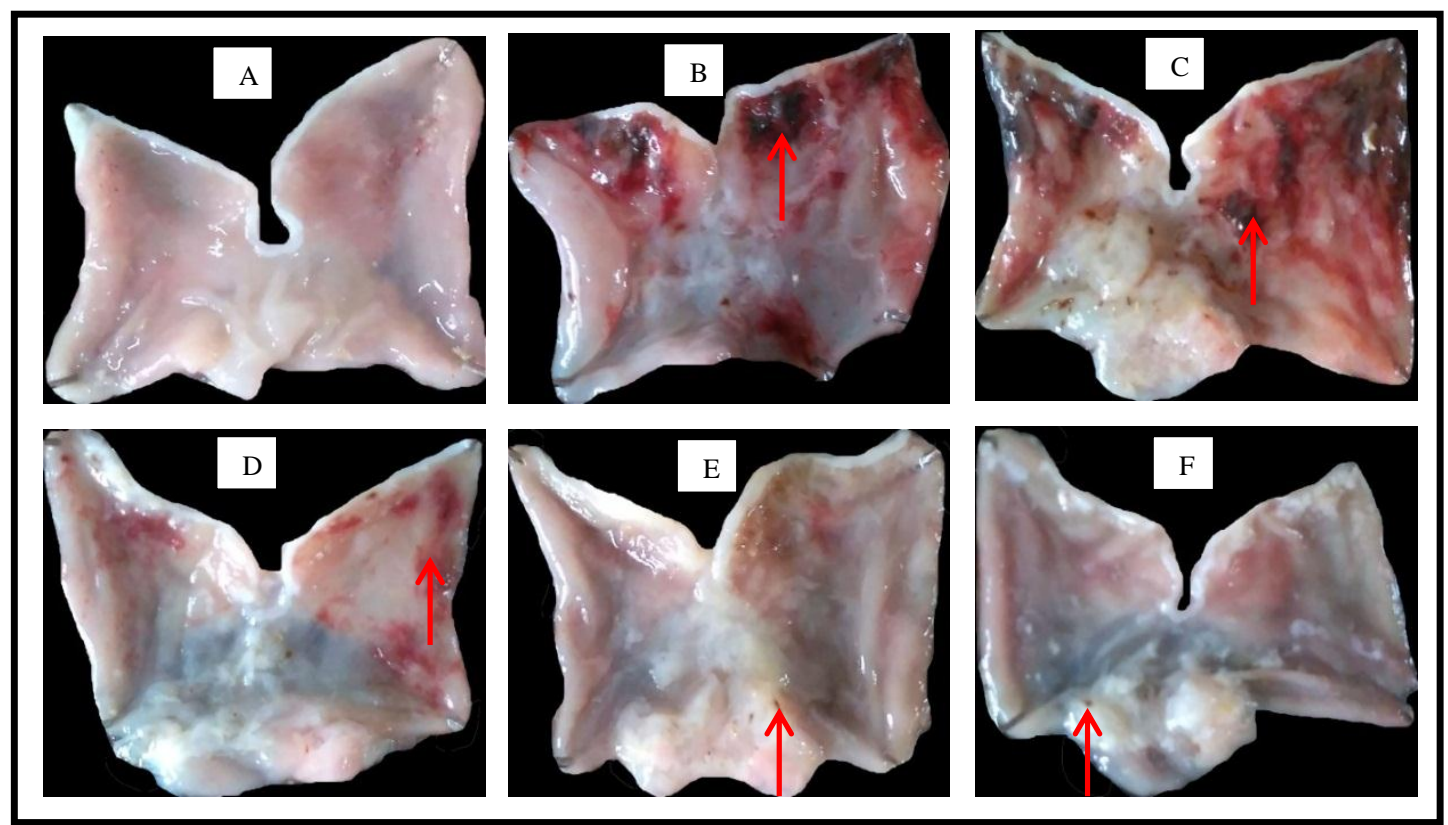

Figure 2. The gastric mucosae of the test rats from the following groups: normal (A), control, induced with $96 \%$ ethanol (B), treated with SCTS at 250 $\mathrm{mg} / \mathrm{kg} \mathrm{BW}(\mathrm{C}), 500 \mathrm{mg} / \mathrm{kg} \mathrm{BW}(\mathrm{D}), 1,000 \mathrm{mg} / \mathrm{kg} \mathrm{BW}(\mathrm{E})$, treated with sucralfate at $360 \mathrm{mg} / \mathrm{kg} \mathrm{BW}$ (F); SCTS: Suspension of Canna edulis Ker. Tuber Starch; The red arrows show the bleeding areas

Table II. The extent of peptic ulcers (\% of bleeding areas), the ulcer index, and the protection ratio of STCS-based treatment

\begin{tabular}{ccccc}
\hline Groups & $\begin{array}{c}\text { Doses } \\
(\mathbf{m g} / \mathbf{k g ~ B W})\end{array}$ & $\begin{array}{c}\text { \% of Bleeding } \\
\text { Areas } \\
(\text { Mean } \pm \text { SD) }\end{array}$ & $\begin{array}{c}\text { Ulcer Index } \\
\text { (Scores) }\end{array}$ & $\begin{array}{c}\text { Protection } \\
\text { Ratio (\%) }\end{array}$ \\
\hline Normal & - & - & $0.0 \pm 0.0^{*}$ & 0 \\
Control & - & $16.59 \pm 4.41$ & $4.0 \pm 0.8$ & 0 \\
SCTS & 250 & $15.38 \pm 5.92^{\#}$ & $3.5 \pm 1.0^{\#}$ & 12.50 \\
& 500 & $8.86 \pm 0.77^{*}$ & $2.0 \pm 0.0^{*}$ & 50 \\
Sucralfate & 1000 & $0.77 \pm 0.18^{*}$ & $1.0 \pm 0.0^{*}$ & 75 \\
\hline Note: *sig<0.05, indicating significant difference with the control group; & * sig $>0.05$, \\
indicating & no significant difference with the control group; SD= Standard \\
Deviation; SCTS: Suspension of Canna edulis Ker. Tuber Starch &
\end{tabular}

Pharmaciana Vol. 8, No. 1, May 2018, Page. 43 - 52 


\section{The histopathological profile of the rat stomach}

In addition to macroscopic observation, this study also conducted microscopic observation through the histopathological test of alcohol-induced peptic ulcers on rat stomach. After interpreting the test results, the rat stomach was treated with Canna edulis Ker. tuber starch, and the effects of the treatment were observed thoroughly.

The slice preparations of the gastric tissue from each group of rats were analyzed qualitatively and quantitatively. The qualitative analysis is illustrated in Figure 3. Meanwhile, the quantitative analysis was performed by assigning a predefined score to each histopathological test preparation. If the stomach was normal (no pathologic changes or tissue repair), the score was 0 . Scores 1,2 , and 3 were for rat stomach that showed an erosion (ulcer), focal erosion, and multifocal erosion, respectively. Score 4 was given to stomach with hemorrhagic focal erosion, while score 5 was assigned to the one with hemorrhagic multifocal erosion. The information acquired from observing the gastric damage levels in each group is presented in Table III.

Based on the histopathological profiles described in Table III, a significant improvement is achieved when the dose of Canna edulis Ker. tuber starch is raised. The observation also showed that the normal group experienced no gastric damage due to the absence of alcohol consumption. This group was used as a comparison for the control group (with alcohol) and the other treatment groups. Furthermore, no damages were found in the sucralfate group and the one treated with Canna edulis Ker. tuber starch at a dose of $1,000 \mathrm{mg} / \mathrm{kg} \mathrm{BW}$. As seen in Table II, these two groups experienced slight damages to their gastric mucosa. Therefore, the preparations observed under a microscope during the histopathological observation might be the part that suffered no lesions or had already experienced gastric tissue repair.

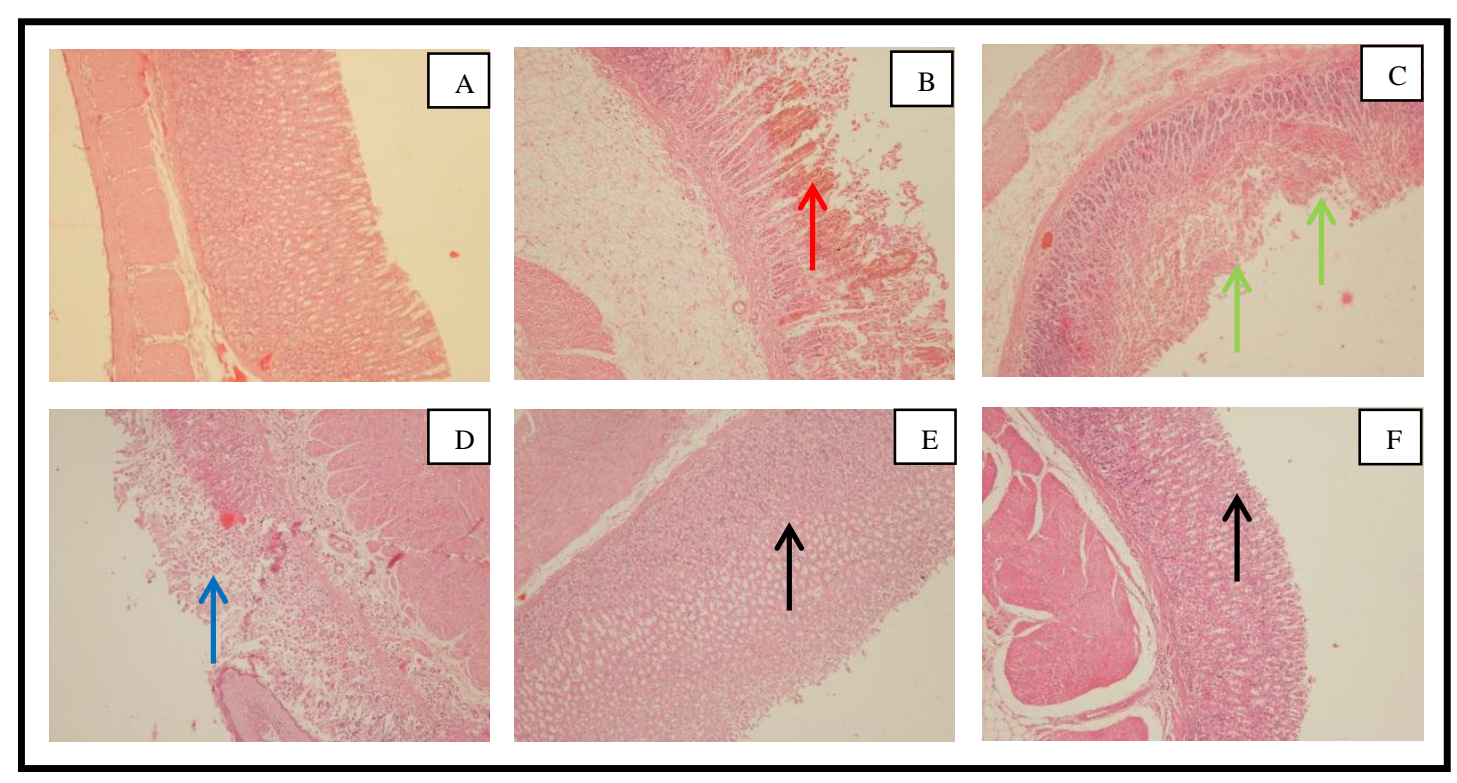

Figure 3. The histopathological profile of rat stomach from the following groups: normal (A), control, induced with $96 \%$ ethanol (B), treated with SCTS at $250 \mathrm{mg} / \mathrm{kg} \mathrm{BW} \mathrm{(C),} 500 \mathrm{mg} / \mathrm{kg} \mathrm{BW}(D), 1,000 \mathrm{mg} / \mathrm{kg} \mathrm{BW}(\mathrm{E})$, treated with sucralfate at $360 \mathrm{mg} / \mathrm{kg} \mathrm{BW}(\mathrm{F})$; 100x magnification; Staining with $\mathrm{HE}$; SCTS: Suspension of Canna edulis Ker. Tuber Starch; The arrows show hemorrhages (red), multifocal erosions (green), focal erosions (blue), and tissue repair (black) 
Table III. The average scores of the damage levels, as identified from the histopathological profiles of rat stomach in a case of SCTS-based treatment

\begin{tabular}{ccc}
\hline Groups & $\begin{array}{c}\text { Doses } \\
(\mathbf{m g} / \mathbf{k g B W})\end{array}$ & $\begin{array}{c}\text { Average Scores } \\
\overline{(\mathbf{X} \pm \mathbf{S D})}\end{array}$ \\
\hline Normal & - & $0.00 \pm 0.00^{*}$ \\
Control & - & $2.75 \pm 1.71$ \\
SCTS & 250 & $3.20 \pm 0.84^{\#}$ \\
& 500 & $2.33 \pm 0.58^{\#}$ \\
Sucralfate & 1000 & $0.00 \pm 0.00^{*}$ \\
& 360 & $0.00 \pm 0.00^{*}$
\end{tabular}

Notes: The average scores are the mean \pm SD of the histopathological preparations; *sig<005 indicates a significant difference with the control group; " indicates no significant difference with the control group; SD = Standard Deviation; SCTS: Suspension of Canna edulis Ker. Tuber Starch.

The gastric damage levels identified from the histopathological profile were analyzed statistically in SPSS 20 with 95\% confidence level. The analysis results showed that there was a significant difference between the histopathological profiles of the control group and the two groups receiving SCTS at 250 and $500 \mathrm{mg} / \mathrm{kg} \mathrm{BW}$. Such significance means that alcohol consumption has a devastating effect on rat stomach. There was no considerable difference between the histopathological profiles of the normal group, the sucralfate-treated group, and the group receiving SCTS at 1,000 $\mathrm{mg} / \mathrm{kg} \mathrm{BW}$ because the last two groups experienced minimal damage (ulcers). Therefore, during the microscopic histopathological observation, the analyzed preparations of both groups might be the parts that suffered no lesions or had already experienced gastric tissue repair.

The results of this study conform with Kusbandari and Lukitaningsih (2013), which affirm that the use of powder simplicia and Canna edulis Ker. tuber starch can decrease the occurrence of acetylsalicylic acid-induced gastrointestinal inflammation and hemorrhage in rats with a protection ratio of $81.13 \%$. However, the protection ratio is different from the one in this study (i.e., $75 \%$ ) due to the dissimilar materials used to induce peptic ulcers in the test animal. Kusbandari \& Lukitaningsih (2013) used acetylsalicylic acid and alcohol that produce different characteristics of peptic ulcers. In acetylsalicylic acid-induced ulcers, the bleeding occurs in the form of lines, while alcohol-induced ulcers appear in blocks of bleeding with a more extensive distribution. Also, the dose of SCTS used in Kusbandari and Lukitaningsih (2013) (i.e., $1,247 \mathrm{~g} / \mathrm{kg}$ ) is higher than the one in this study.

Other studies find that the infusion of Canna edulis Ker. contains flavonoid and, at the same time, prove that this plant has anti-ulcerogenic activity (Lestari, 2004) and that the juice of its tuber can serve as antiulcer (Lestari, 2008). Flavonoids work by inhibiting cyclooxygenase enzyme activity and the formation of prostaglandins from arachidonic acid. This inhibition reduces the inflammation of gastric cells (Miller, 2003), counteracts free radicals that play a role in the pathogenesis of peptic ulcer (de Lira Mota et al., 2009), triggers tissue repair through the expression of various growth factors (Kim et al., 2004), and reacts with any Reactive Oxygen Species (ROS) (Pastrana-Bonilla et al., 2003; Liu et al., 2002).

Increasing carbohydrates intake by consuming Canna edulis Ker. tuber starch is another possible mechanism to prevent peptic ulcers. Carbohydrates are known to block muscarinic acetylcholine and histamine receptors, function as Proton pump inhibitors, increase the regeneration of gastric epithelial cell, raise the bold supply in gastric tissue, and improve mucosal hydrophilicity, all of which play a vital role in maintaining stomach balance (Rajashekhara et al., 2014). 


\section{CONCLUSION}

This research affirms that Canna edulis Ker. tuber starch (SCTS) exhibits a gastroprotective effect. When administered at a dose of $1,000 \mathrm{mg} / \mathrm{kg} \mathrm{BW}$, it increases the protection ratio against alcohol-induced ulcers up to $75 \%$. Based on the histopathological profile, at this dose, SCTS promotes the best gastric tissue repair. The total flavonoid content of Canna edulis Ker. tuber starch is $112.49 \pm$ $7.97 \mathrm{ppm}$

\section{REFERENCES}

Abdel-Raheem, I. T., 2010. Gastroprotective effect of rutin against indomethacin-induced ulcers in rats, Basic and Clinical Pharmacology and Toxicology, 742-750.

de Lira Mota, K. S., Dias, G. E., Pinto, M. E., Lima, C. A., Ferreira, A. L., Brito, A. R., 2009. Flavonoids with Gastroprotective Activity, Molecules, 979-1012.

Falcao, H. d., Leite, J. A., Barbosa-Filho, J. M., de Athayde-Filho, P. F., de Oliveira Chaves, M. C., Moura, M. D., 2008, Gastric and duodenal antiulcer activity of alkaloids : a review. Molecules, 3198-3223.

Guyton, A.C., and Hall, J.E., 2008. Buku Ajar Fisiologi Kedokteran, edisi 11, EGC Penerbit Buku Kedokteran, Jakarta.

Hariana, A., 2013, 262 Tumbuhan Obat dan Khasiatnya, Penebar Swadaya, Jakarta.

Kim, S. C., Byun, S. H., and Yang, C. H., 2004, Cytoprotective effects of glycyrrhizae radix extract and its active component liquiritigenin against cadmium-induced toxicity (effects on bad translocation and cytochrome c-mediated PARP cleavage), Toxicology, 197(3): 239-251.

Kusbandari, A. and Lukitaningsih, E., 2013, Analisis kandungan karbohidrat dan nilai indeks glisemik serta aktivitas anti ulser dan anti kolesterol umbi ganyong (Canna Edulis Ker.), Tesis, Fakultas Farmasi, Universitas Gadjah Mada, Yogyakarta.

Lestari, P., 2008, Uji efek antiulcer perasan umbi ganyong (Canna edulis Ker.) pada tikus putih jantan galur wistar, Skripsi, Fakultas Farmasi, Universitas Muhammadiyah Surakarta.

Lestari, W.P., 2004, Infusa Umbi Ganyong (Canna edulis Ker): Pengaruhnya terhadap ulkus peptik tikus jantan karena salisilat dan profil kromatografi lapis tipisnya, Skripsi, Fakultas Farmasi, Universitas Gadjah Mada, Yogyakarta.

Liu, C.F., Lin, C.C., Lin, M.H., Lin, Y.S., and Lin, S.C., 2002. Cytoprotection by propolis ethanol extract of acute absolute ethanol-induced gastric mucosal lesions, The American Journal of Chinese Medicine, 30(2-3): 245-254.

Maslachah, L., Sugihartini, R., and Ankestri, H., 2008. Description of white rat (Rattus norvegicus) intestine that was given juice of noni (Morinda citrifolia) and high fatty diet, Veterinaria Medika, 1(3): 103-108.

Miller, A.L., 2003. Antioxidant Flavonoids: Structure, Function and Clinical Usage, Alternative Medicine Review, 1(2): 103-111.

Mishra, T., Das, AP., and Sen, A., 2011. Phytochemical screening and in-vitro antioxidant profiling of solvent fractions of Canna edulis Ker Gawler, Free Radicals and Antioxidants, 2(1):13-20.

Pastrana-Bonilla, E., Akoh, C.C., Sellappan, S., and Krewer, G., 2003. Phenolic content and antioxidant capacity of muscadine grapes, Journal of Agricultural and Food Chemistry, 51(18): 5497-5503.

Pertiwi, R. and Bachri, MS., 2016. Efek gastroprotektor ekstrak etanol umbi garut (Maranta arundinacea L.) terhadap indeks tukak lambung, rasio proteksi, ekspresi protein COX-2 dan gambaran histopatologis lambung pada tikus model tukak lambung, Tesis, Fakultas Farmasi, Universitas Ahmad Dahlan, Yogyakarta.

Pospos, N.S., 2002. Bukti gambar, etanol merusak sel hati dan pengaruhnya terhadap konsentrasi ATP intraseluler, Medika, 1(27): 17-20.

Rajashekhara, N., Ashok, B. K., Parmeshwar, Sharma. P., Ravishankar, B., 2014. The evaluation of anti-ulcerogenic effect of rhizome starch of two source plants of Tugaksheeree (Curcuma 
angustifolia Roxb. and Maranta arundinacea Linn.) on pyloric ligated rats, An International Quartely Journal of Research in Ayurveda, 35(2): 191-196.

Saptarini, N.M., Suryasaputra, D., and Saepulhak, A.M., 2011. Analisis rasio proteksi antiulser sari buah pepino (Solanum muricaum Aiton) menggunakan tikus sebagai model hewan coba, Majalah Obat Tradisional, 16 (2): 75-80.

Turner, JR., 2010. The Gastrointestinal Tract, In Robbins and Cotran: Pathologic Basis of Disease, 8th edition, Philadelphia, Saunders Elsevier.

Wardhani, L.K., and Sulistyani, N., 2012. Antibacterial activity test of ethyl acetate extract of binahong leaf (Anredera scandens (L.) Moq.) against Shigella flexneri with the profile of thin layer chromatography, Jurnal Ilmiah Kefarmasian, 2(1): 1-16.

Wibisono, A.S, 2012. Keracunan alkohol beracun, Majalah Kedokteran Terapi Intensif, Laporan Kasus, 2(2), Jakarta.

Yanwirasti, 2008. Langkah-langkah Pokok Penelitian Biomedik, Fakultas Kedokteran Universitas Andalas, Padang.

Yuangsoi, B., Jintasataporn, O., Areechon, N. and Tabthipwon, P., 2008. Validated TLC-densitometric analysis for determination of carotenoids in fancy carp (Cyprinus carpio) serum and the application for pharmacokinetic parameter assessment, Songklanakarin J. Sci. Technol., 30(6), 693-700. 